\title{
Cinico-Epidemiological Profile of Vitiligo Patients in Dr. Hasan Sadikin General Hospital Bandung
}

\author{
Reiva Farah Dwiyana, ${ }^{1}$ Vani Marindani, ${ }^{1}$ Rohana Agustina, ${ }^{1}$ Setiawan, ${ }^{2}$ Ponpon S. Idjradinata ${ }^{3}$ \\ Endang Sutedja ${ }^{1}$ \\ ${ }^{1}$ Department of Dermato-Venerology Faculty of Medicine Universitas Padjadjaran/Dr. Hasan Sadikin General \\ Hospital, Bandung, ${ }^{2}$ Department of Anatomy, Biology Cell, and Physiology Faculty of Medicine \\ Universitas Padjadjaran ${ }^{3}$ Department of Child Health Faculty of Medicine Universitas Padjadjaran \\ Dr. Hasan Sadikin General Hospital Bandung
}

\begin{abstract}
Vitiligo is the most common hypopigmentation disorder; however, until now there iss no comprehensive epidemiological-clinical study of vitiligo in Indonesia. A descriptive study using a questionnaire among vitiligo patients in Dr. Hasan Sadikin General Hospital Bandung was conducted to determine the clinical findings, sociodemographic factors, coexisting autoimmune disorders, and severity of disease. All vitiligo patients were recruited during the period of February 2012 to April 2014 from the Dermatology Outpatient Clinic of Dr. Hasan Sadikin General Hospital Bandung, as well as from the Endocrinology and Rheumatology Clinic Department of Internal Medicine; Endocrinology and Allergy and Immunology Clinics Department of Child Health; and Department of Nuclear Medicine the same hospital. We collected data on socio-demographic profiles, clinical profile, and severity of vitiligo based on Vitiligo European Task Force (VETF). Out of 242 patients, female patients made up the majority of the patients (66.12\%). In addition, most patients wereunder 20 years (33.47\%) and experienced onset of vitiligo highest in the first decade of life (29.34\%). About $19.42 \%$ had positive family history of vitiligo and only $6.2 \%$ had history of autoimmune diseases. The majority of patients (77.27\%) had vulgaris type of vitiligo with head-neck (35.36\%) asthe most frequent initial site of onset. Based on VETF, the skin affected was mostly below $10 \%$ of body surface area (82.23\%), i.e. staging score of between 0-5 (57.44\%), and spreading score of between $>0-(+5)$ or $68.18 \%$. It is concluded that vitiligo most commonly occurs in females with the highest onset of under 10-years old and strong relationship with genetic predisposition.T he affected area was relatively small, despite the high spreading score. [MKB. 2017;49(2):132-8]
\end{abstract}

Key words: Clinical profile, epidemiology, vitiligo

\section{Profil Kliniko-Epidemiologi pada Pasien Vitiligo di RSUP Dr. Hasan Sadikin Bandung}

\begin{abstract}
Abstrak
Vitiligo merupakan kelainan hipopigmentasi tersering, tetapi hingga kini belum ada penelitian epidemiologiklinik yang komprehensif di Indonesia. Penelitian deskriptif menggunakan kuesioner dilakukan pada pasien vitiligo di Rumah Sakit Dr. Hasan Sadikin Bandung untuk mengetahui gambaran klinis, faktor sosio-demografik, kelainan autoimun yang menyertai, dan keparahan penyakit. Seluruh pasien vitiligo dari periode Februari 2012 hingga April 2014 yang berkunjung ke poliklinik Kulit dan Kelamin Rumah Sakit Dr. Hasan Sadikin Bandung, serta poliklinik: Endokrinologi dan Rematologi, Ilmu Penyakit Dalam; Endokrinologi dan Alergi-imunologi, Ilmu Kesehatan Anak; serta Kedokteran Nuklir, diikutsertakan dalam penelitian. Data yang dihimpun mencakup keadaan sosiodemografi, klinik, dan keparahan vitiligo berdasar atas Vitiligo European Task Force (VETF). Dari 242 pasien, perempuan merupakan jenis kelamin terbanyak (66,12\%), usia di bawah 20 tahun $(33,47 \%)$, dan awitan vitiligo terjadi pada dekade pertama kehidupan (29,34\%). Sekitar 19,42\% memiliki riwayat vitiligo pada keluarga dan hanya $6,2 \%$ yang memiliki penyakit autoimun. Umumnya tipe vitiligo vulgaris $(77,27 \%)$ dengan predileksi pertama pada kepala-leher (35,36\%). Area kulit yang terkena berdasarkan VETF ialah di bawah $10 \%$ dari body surface area (82,23\%), staging score 0-5 (57,44\%), dan spreading score antara $>0-(+5)$ atau 68,18\%. Simpulan penelitian ini ialah vitiligo banyak mengenai perempuan, awitan tersering pada usia di bawah 10 tahun dengan predisposisi genetik yang tinggi, serta daerah yang terkena vitiligo relatif kecil meskipun spreading scorenya tinggi. [MKB. 2017;49(2):132-8]
\end{abstract}

Kata kunci: Epidemiologi, gambaran klinik, vitiligo

Correspondence: Dr. Reiva Farah Dwiyana, dr., Sp.KK, M. Kes, Department of Dermato-Venerology Faculty of Medicine Universitas Padjadjaran/Dr. Hasan Sadikin General Hospital Bandung, Email: reiva.farah@yahoo.co.id 


\section{Introduction'}

Vitiligo is an acquired depigmenting disorder characterized by the loss of functional melanocytes from the epidermis. ${ }^{1,2}$ Vitiligo affecting between $1 \%$ and $2 \%$ of the general population without any racial, sexual, or regional differences in prevalence. ${ }^{1,3}$ Vitiliginous patches contain either reduced melanin or no pigment at all, ${ }^{2}$ usually as initial small lesion, but they may enlarge and coalescence into larger patches. ${ }^{4}$

The etiology of vitiligo is uncertain, although genetic, immunological, and neurogenic factors seem to play a role. ${ }^{2}$ About one-third people affected vitiligo have family history, but there are few epidemiological studies to confirm this. However, certain triggers (e.g. trauma to the skin, hormonal changes, and stress) may be necessary for the disease to become apparent. ${ }^{2,3}$ Autoimmune mechanisms are thought to be responsible in the pathogenesis of vitiligo (especially in generalized or focal non-dermatomal vitiligo). Furthermore, vitiligo is often associated with autoimmune diseases, such as thyroid diseases, pernicious anemia, and diabetes mellitus. ${ }^{1,3}$ Regarding segmental vitiligo, the neural hypothesis suggests that it is due to an accumulation of a neurochemical substance, which decreases melanin production. ${ }^{4}$

Vitiligo can be separated into segmental and nonsegmental types. In nonsegmental vitiligo, there is usually symmetric distribution of lesions and new patches may appear throughout the patient's life. It may be either generalized or localized. ${ }^{1,2}$ In generalized, nonsegmental vitiligo usually has widespread distribution of depigmented patches. Vitiligo that has extensive lesions with few normally pigmented patches known as vitiligo universalis. Acrofacial vitiligo skin involvement is limited to the distal digits and periorificial facial areas. Focal vitiligo lesions are limited in quantity and location and have a non-dermatomal distribution. It may develop into generalized vitiligo or may follow an earlystabilizing clinical course. Segmental vitiligo has important differences in etiology, prevalence of associated illnesses and therapy compared to other forms of vitiligo. It usually has unilateral involvement and dermatomal distribution. ${ }^{1-4}$ Unfortunately, until now, there is lack of literature about profile of vitiligo patients in Indonesia.

\section{Methods}

All patients presenting with signs and symptoms suggestive vitiligo seen over a period from February 2012 to April 2014 at the Dermatology Outpatient Dr. Hasan Sadikin General Hospital Bandung, also from Endocrinology Outpatient (period February-March 2012), Rheumatology Outpatient (period March-April 2012), Pediatric Endocrinology, Pediatric Allergy and Immunology, and Nuclear Medicine Outpatient (period April-May 2012) were included in this study. Sociodemographic details about age, sex, address, ethnic, marital status, education, occupation, family tree were recorded in a questionnaire. A detailed clinical history of vitiligo, associated autoimmune and other disorder were also noted in same questionnaire. Clinical examination also carried out to determine percentage, staging, and spreading score of vitiligo based on Vitiligo European Task Force. Data was calculated by percentage to know the incidence and other statistic results.

\section{Results}

From February 2012 until April 2014, there were 242 vitiligo patients who attended to Dr. Hasan Sadikin General Hospital Bandung. Among them, 209 patients came to Dermatology Outpatient, 14 patients came to Endocrinology Outpatient, five patients came to Rheumatology Outpatient, and six patients are family member that accompany non-vitiligo patients.

There were 243 vitiligo patients from 4,675 patients of Dermatology Outpatient from Juni 2012 until April 2014 (5.01\%). In Endocrinology Outpatient there were 14 vitiligo patients from 1,457 patients of from February until March $2012(0.96 \%)$ and 5 patients from 764 patients of Rheumatology Outpatient from March until April $2012(0.65 \%)$. None patients of vitiligo were found from 59 patients in Pediatric Outpatient (Division of Immunology and Endocrinology) and from 135 autoimmune patients in Department of Nuclear Medicine.

Among 977 autoimmune patients in Dermatology Outpatient, 234 were vitiligo (23.95\%) and in other clinic: 14 patients vitiligo from 122 autoimmune patients of Endocrinology Outpatient Clinic (12.39\%), as well as 5 patients from 132 autoimmune patients of Rheumatology Outpatient (3.03\%). There was no vitiligo patient in Pediatric Endocrinology Outpatient, Pediatric Allergy and Immunology Outpatient, and Nuclear Medicine Outpatient.

Total number of female with vitiligo were $160(66.12 \%)$ and the total number of males 
Table 1 Sociodemographic Profile

\begin{tabular}{|c|c|c|}
\hline & Number of Patients & Percentage (\%) \\
\hline \multicolumn{3}{|c|}{ (1) } \\
\hline Male & 82 & 33.88 \\
\hline Female & 160 & 66.12 \\
\hline \multicolumn{3}{|l|}{ Age } \\
\hline$\leq 20$ y.o & 81 & 33.47 \\
\hline$>20$ y.o & 161 & 66.53 \\
\hline \multicolumn{3}{|l|}{ Marital Status } \\
\hline Unmarried & 100 & 41.32 \\
\hline Married & 139 & 57.44 \\
\hline Divorce & 3 & 1.24 \\
\hline \multicolumn{3}{|l|}{ Occupation } \\
\hline Unemployee & 16 & 6.61 \\
\hline Retired & 19 & 7.85 \\
\hline Students & 75 & 30.99 \\
\hline House wife & 52 & 21.49 \\
\hline \multicolumn{3}{|l|}{ Private and Civil servant } \\
\hline Indoor & 61 & 25.21 \\
\hline Outdoor & 19 & 7.85 \\
\hline \multicolumn{3}{|l|}{ Education } \\
\hline Uneducated & 40 & 16.53 \\
\hline $1-12^{\text {th }}$ grade & 144 & 59.50 \\
\hline Graduation and above & 58 & 23.97 \\
\hline \multicolumn{3}{|l|}{ Ethnic } \\
\hline Sundanese & 178 & 73.55 \\
\hline Javanese & 31 & 12.81 \\
\hline Minang & 5 & 2.07 \\
\hline Others ethnic & 8 & 2.89 \\
\hline Mixed ethnic & 21 & 8.68 \\
\hline
\end{tabular}

with the disease were $82(33.88 \%)$ as shown in Table 1. Eighty-one patients (33.47\%) were $\leq 20$ years and the rest of them are above 20 years (161 patients/ 66.53\%). The youngest age was one-year old and the oldest age was 77-year old. In this study, the mean \pm SD age of the patients at the time of study was $33.75 \pm 19.63$ years.

A detailed sociodemographic profile of the patients was shown in Table 1. Majority patients were married (57.44\%), three patients got divorced $(1.24 \%)$, and 100 patients were unmarried (41.32\%). From 242 patients, 16 patients were unemployee $(6.61 \%), 75$ patients were student (30.99\%), 19 patients were retired (7.85\%), 52 patients were housewife (21.49\%), 80 were private employees and civil servant, consist of 19 outdoor employees (7.85\%) and 61 indoor employees (25.21\%).

Fourty patients were uneducated (16.53\%), 144 patients were in $1-12$ grade $(59.50 \%)$, and 58 patients were graduation and above (23.97\%). Ethnicity of the patients were various, majority patients are Sundanese (73.55\%), others are Javanese (12.81\%), mixed ethnic (8.68\%), and Minang (2.07\%).

\section{Discussion}

In this study, female patients was much more than male patients (66.12\%: 33.88\%). Many studies showed that female vitiligo patients was more often than male. Female preponderance was observed in Al Mutairi and Sharma study (58\%). ${ }^{5}$ 
Reiva Farah Dwiyana: Cinico-Epidemiological Profile of Vitiligo Patients in Dr. Hasan Sadikin General Hospital Bandung

Table 2 Family History of Vitiligo Patients

\begin{tabular}{lcc}
\hline $\begin{array}{l}\text { Family History of } \\
\text { Vitiligo }\end{array}$ & $\begin{array}{c}\text { Number } \\
\text { of } \\
\text { Patients }\end{array}$ & (\%) \\
\hline $\begin{array}{l}\text { First degree relatives } \\
\quad \text { Father }\end{array}$ & 4 & 1.65 \\
$\quad$ Mother & 3 & 1.24 \\
$\quad$ Brother/sister & 9 & 3.72 \\
$\quad$ Children & 4 & 1.65 \\
Second degree relatives & & \\
$\quad$ Paternal \\
grandparents & 5 & 2.07 \\
$\quad$ Maternal & & \\
$\quad$ grandparents & 3 & 1.24 \\
$\quad$ Maternal/paternal & 13 & 5.37 \\
$\quad$ uncle/aunt & & \\
Third degree relatives & & \\
$\quad$ Cousin & 6 & 0 \\
$\quad$ Niece/nephew & 0 & 19.42 \\
Total & 47 & \\
\hline
\end{tabular}

Shah et $\mathrm{al}^{6}$ also referred to a preponderance of females among patients with vitiligo $68.34 \%$.

In a study on Turkish patients, Arýcan stated that $54.5 \%$ of cases were men. Alkhateeb and Ersoy ${ }^{7}$ in a recent study from USA have noted that the frequency of vitiligo appeared approximately equal in males and females. Al Mutairi and Sharma ${ }^{5}$ felt that female preponderance in their cases is presumably for two reasons; first, the higher cosmetic concern among female patients and the relatively more time they have for long-term therapy allowing them to seek active treatment more often; and second, males being bread earners in contemporary society, must work all day long throughout the year and this

Table 4 Onset of Vitiligo

\begin{tabular}{lcc}
\hline Onset of Vitiligo & $\begin{array}{c}\text { Number of } \\
\text { Patients }\end{array}$ & (\%) \\
\hline $1-10$ y.o & 71 & 29.34 \\
$11-20$ y.o & 49 & 20.25 \\
$21-30$ y.o & 33 & 13.64 \\
$31-40$ y.o & 29 & 11.98 \\
$41-50$ y.o & 28 & 11.57 \\
$51-60$ y.o & 18 & 7.44 \\
$>60$ y.o & 13 & 5.37 \\
Unknown & 1 & 0.41 \\
\hline y.o = years old & &
\end{tabular}

Table 3 Type of Vitiligo

\begin{tabular}{lcc}
\hline Type of Vitiligo & $\begin{array}{c}\text { Number of } \\
\text { Patients }\end{array}$ & (\%) \\
\hline Segmental & 20 & 8.26 \\
Non-segmental & & \\
Localized & 21 & 8.68 \\
Akrofacial & 12 & 4.96 \\
Vulgaris & 187 & 77.27 \\
Universalis & 2 & 0.83 \\
\hline
\end{tabular}

makes them relatively unconcerned or so busy to consult for the treatment of vitiligo. Shah et al. ${ }^{6}$ also said that females outnumbered males in their study presumably because social stigma and marital concerns prompt women to seek early consultation.

In this study, the mean $\pm \mathrm{SD}$ age of the patients at the time of study was $33.75 \pm 19.63$ years. It is different with the study result of Mchepange et al. at China with the mean of age 26.9 years and Arýcan at Turki 23 years. This was because in this study, patients were old patients who had been a long time getting phototherapy treatment, so that age older than obtained in other studies.

Genetic factors play an important role in the onset of the vitiligo disease. In Table 2 shows that vitiligo patients had family history of vitiligo disease (19.42\%). In another study, there were varying percentages, Shah et al. ${ }^{6} 13.7 \%$, AlMutairi and Sharma ${ }^{5}$ 18.95\%, and Shajil et al. ${ }^{2}$ $21.96 \%$.Vitiligo had a polygenic or autosomal dominant inheritance pattern with incomplete penetrance and variable expression. Familial occurance had been reported to vary from 6.25$30 \%$. Positive family history was considered to be a poor prognostic factor., ${ }^{2,5-8}$

In Table 2 shows the highest sequence in the first-degree relatives $(8.26 \%)$, second degree $(8.68 \%)$, and then the third degree $(2.48 \%)$. This result consistent with research Shajil et al. ${ }^{2}$ with first degree relatives, second; third, $13.68 \%$,

Table 5 Site of Onset

\begin{tabular}{lcc}
\hline Site of Onset & $\begin{array}{c}\text { Number of } \\
\text { Cases }\end{array}$ & $\begin{array}{c}\text { Percentage } \\
\text { (\%) }\end{array}$ \\
\hline Head and neck & 88 & 36.36 \\
Trunk & 51 & 21.07 \\
Upper limb & 14 & 5.79 \\
Lower limb & 30 & 12.40 \\
Acral & 59 & 24.38 \\
\hline
\end{tabular}


Table 6 Course of Disease

\begin{tabular}{|c|c|c|}
\hline & Number of Cases & Percentage (\%) \\
\hline \multicolumn{3}{|l|}{ Spontaneous repigmentation } \\
\hline Yes & 63 & 26.03 \\
\hline No & 178 & 73.55 \\
\hline \multicolumn{3}{|c|}{ Progressivity in last six month } \\
\hline Progressive & 158 & 65.29 \\
\hline Stabile & 70 & 28.93 \\
\hline Regression & 13 & 5.37 \\
\hline \multicolumn{3}{|l|}{ History of treatment } \\
\hline Yes & 211 & 87.19 \\
\hline No & 31 & 12.81 \\
\hline \multicolumn{3}{|l|}{ Result of treatment } \\
\hline Improvement & 94 & 44.55 \\
\hline No improvement & 114 & 54.03 \\
\hline \multicolumn{3}{|c|}{ Predisposing and precipitating factor } \\
\hline Sun exposure & 156 & 64.46 \\
\hline Koebner phenomenon & 78 & 32.23 \\
\hline \multicolumn{3}{|l|}{ Percentage of vitiligo lesion } \\
\hline Unknown & 2 & 0.83 \\
\hline$\leq 10 \%$ & 199 & 82.23 \\
\hline $10-20 \%$ & 22 & 9.09 \\
\hline $20-30 \%$ & 8 & 3.31 \\
\hline $30-40 \%$ & 4 & 1.65 \\
\hline $40-50 \%$ & 4 & 1.65 \\
\hline $50-60 \%$ & 0 & 0 \\
\hline $60-70 \%$ & 1 & 0.41 \\
\hline $70-80 \%$ & 0 & 0 \\
\hline $80-90 \%$ & 0 & 0 \\
\hline$>90 \%$ & 2 & 0.83 \\
\hline \multicolumn{3}{|l|}{ Staging } \\
\hline $0-5$ & 139 & 57.44 \\
\hline $6-10$ & 98 & 40.50 \\
\hline $11-15$ & 3 & 1.24 \\
\hline $16-20$ & 2 & 0.83 \\
\hline \multicolumn{3}{|l|}{ Spreading } \\
\hline$-5-<0$ & 33 & 13.64 \\
\hline 0 & 41 & 16.94 \\
\hline$>0-(+5)$ & 165 & 68.18 \\
\hline
\end{tabular}

$5.66 \%, 2.59 \%,{ }^{9}$ and Shah et al. ${ }^{6} 9.59 \%, 3.56 \%$; $0.55 \%$.

Vitiligo vulgaris was the most common type of disease in this study followed by localized, acrofacial, segmental, and universal. In Shah et al. ${ }^{6}$ study in India also showed that vitiligo vulgaris $(77.78 \%)$ was the most common morphological pattern. Al Mutairi an Sharma ${ }^{5}$ also reported vitiligo vulgaris is also the most common clinical-type skin disorder observed in Kuwait followed by focal vitiligo, acrofacial vitiligo, mucosal vitiligo, segmental vitiligo and universal vitiligo types.

Onset of vitiligo disease was highest in the first 10 years of life (29.34\%), followed by 10 second year $(20.25 \%)$, in this study. The youngest age of vitiligo disease arising in this study is one-year old, while the oldest was 73 
years of age. According to Liu et al. ${ }^{10}$ with the highest age onset of vitiligo at the age of 30 years as many as $73 \%$.

Patients have numerous treatment options available, but none was universally effective. Even among patients who respond to treatment, there was a high potential for relapse. ${ }^{11}$ Vitiligo can devastate psychological effects on the patient due to cosmetic disfigurement and treatment difficulties. Patients with vitiligo treated at dermatology clinics should be assessed in terms of psychiatric disorders and psychiatric interventions may become necessary in the course of illness. ${ }^{11,12} \mathrm{~A}$ paramount factor for treatment compliance and psychological well being of the patient is society's response in general towards victims of this disease. The perception of population towards vitiligo differs in terms of disease seriousness, infectivity, availability of treatment and duration of therapy 11-13. This condition affects other family member, usually for the parents that have children with vitiligo. They usually feel uncomfortable and blame people that looking for their children's skin condition. Similar respond affects family member which become stressful if their related is being hospitalized in Intensive Care Unit at Hospital. ${ }^{14}$

The psychological impact of vitiligo varies greatly from person to person, depending on their condition, their social and occupational situation and their psychological wellbeing. Vitiligo was often most obvious in darkly pigmented individuals, in whom the disease can have profound psychological consequences. These effects range from mild embarrassment to a severe loss of self-confidence and social anxiety, especially for those who have lesions on exposed skin. ${ }^{11-13}$

In an interesting study from Belgium investigating the attitude of treating dermatologists, it was revealed that due to pessimistic attitude of treating physician themselves about expected treatment results, only $36 \%$ of them had encouraged their patients to undergo treatment. This attitude can also be reflected by the patient him/herself. Vitiligo can be treated properly, depending on the attitudes of their parents, relatives, teachers, friends, baby sitters, etc. ${ }^{21}$

Koebner phenomenon is reported that has an association with vitiligo disease. Koebnerization was observed in $32.23 \%$ our patients. Al Mutairi and Sharma ${ }^{5}$ have reported it in $23 \%$ and Barona et al. reported it in $57.9 \%$. Koebnerization occurs in most people with vitiligo, but elimination of frictional trauma, in the form of occlusive garments and jewellery, prevents occurrence of new lesions in the cosmetically important areas in cases of progressive vitiligo. Also, it has been reported that the presence of positive experimentally induced Koebner phenomenon was associated with active disease, but not necessarily more severe disease (that is, in terms of the extent of depigmentation). The presence of Koebner phenomenon may be a valuable clinical factor for assessing disease activity, and may predict responsiveness to certain treatments. . $^{5,15}$

In this study, only $26.03 \%$ of patients that had spontaneous repigmentation, rest of them $(73.55 \%)$ did not had spontaneous repigmentation. Taieb and Picardo in Consensus Report of Vitiligo European Task Force also reported that only $17 \%$ of their cases had spontaneous repigmentation. About $42.8 \%$ did not had previous episodes of repigmentation, $26.3 \%$ repigmentation after treatment, and 13\% repigmentation after sun exposure.

The head-neck was the initial site of onset of vitiligo in majority (36.36\%), followed by acral, trunk, lower limb, and upper limb. Al Mutairi and Sharma ${ }^{5}$ reported that the most common site of onset was lower limbs followed by, upper limbs, head and neck, trunk, genitalia and mucous. While Arýcan and Ersoy ${ }^{7}$ reported that the most common site of onset was upper limb.

Association of vitiligo with other autoimmune diseases had been reported at frequencies ranging from $4.76 \%$ to $7.6 \%$ in China. ${ }^{16}$ Two of the major theories of the pathogenesis of vitiligo are the autoimmune theory and the autocytotoxicity theory. Reports on association of vitiligo with other autoimmune diseases vary widely depending on the patient populations studied. ${ }^{17}$ Age of patients at the time of study, the number of autoimmune diseases analyzed, as well as the patient's ability to distinguish different forms of autoimmune diseases also affect the accuracy of the frequencies reported.

History of autoimmune diseases associated with vitiligo includes thyroid disease, gastritis, diabetes, lupus erythematosus, Addison's disease, pernicious anemia, and arthritis. Based on research in China, Mchpange et al. ${ }^{8}$ reported that among vitiligo patients who had autoimmune diseases was small (3.8\%), including hyperthyroidism (22.2\%), rheumatoid arthritis $(18.5 \%)$, and alopecia areata $(14.8 \%)$. Not much different from Akrem et al. ${ }^{18}$ in Tunisia, who reported that patients with vitiligo who had autoimmune diseases by $3.4 \%$.

The clinico-epidemiology profiles in this 
study including most seen in female, most frequent onset was in childhood, with majority vitiligo vulgaris type, and head-neck was initial site. Genetic predisposition in this study was high. Area affected vitiligo relative small, although spreading score was high.

\section{Acknowledge}

Authors would like to thank to former Head of Department of Dermatology: dr.Yono Hadi Agusni, Sp.KK(K); and current Head of Department of Dermatology: Dr. Oki Suwarsa, dr.SpKK(K), M.Kes; Head of Division of Rheumatology, Department of Internal Medicine: dr. Rahmat Gunadi Wachyudi, SpPD-KR; Head of Division of Endocrinology, Department of Pediatric: dr. R.M. Ryadi Fadil, $\mathrm{SpA}(\mathrm{K})$, M.Kes; Head of Division of Allergy and Immunology, Department of Pediatric: Prof. Dr. Budi Setiabudiawan, dr. SpA(K), M.Kes; and Head of Department of Nuclear Medicine: Dr. Achmad Hussein S. Kartamihardja, dr. SpKN(K), M.H.Kes, all from Faculty of Medicine Padjadjaran University/Dr. Hasan Sadikin General Hospital Bandung, for their kind supports to our work in screening patients in their outpatient clinics.

\section{References}

1. Westerhof W, d'Ischia M. Vitiligo puzzle: the pieces fall in place. Pigment Cell Res. 2007;20(5):345-59.

2. Shajil EM, Chatterjee S, Agrawal D, Bagchi T, Center R. Vitiligo: Pathomechanisms and genetic polymorphism of susceptible genes. Indian J Exp Biol. 2006;44(7):526-39.

3. Felsten LM, Alikhan A, Petronic-Rosic V. Vitiligo: a comprehensive overview part II: treatment options and approach to treatment. J Am Acad Dermatol. 2011;65(3):493-514.

4. Schallreuter KU, Bahadoran P, Picardo M, Slominski A, Elassiuty YE, Kemp EH, et al. Vitiligo pathogenesis: autoimmune disease, genetic defect, excessive reactive oxygen species, calcium imbalance, or what else? Exp Dermatol. 2008;17(2):139-60.

5. Al-Mutairi N, Sharma AK. Profile of vitiligo in
Farwaniya Region in Kuwait. Kuwait Med J. 2006;38(2):128-31.

6. Shah H, Mehta A, Astik B. Clinical and sociodemographic study of vitiligo. BMC. 2006;2:132-36.

7. Arýcan Ö, Ersoy L. Clinical characteristics in 113 Turkish vitiligo patients. Acta Dermatoven APA. 2008;17(3):129-32.

8. Mchepange UO, Gao X-H, Liu Y-Y, Liu Y-B, Ma L, Zhang L, et al. Vitiligo in North-eastern China: an association between mucosal and acrofacial lesions. Acta DermatoVenereologica. 2010;90(2):112-5.

9. Shajil EM, Agrawal D, Vagadia K, Marfatia YS, Begum R. Vitiligo: clinical profile in Vadodara, Gujarat. Indian J Dermatol. 2006;51(2):1004.

10. Liu J, Li M, Yang S. Clinical profiles of vitiligo in China: an analysis of 3742 patients. Clin Exp Dermatol. 2005;30(4):327-31.

11. Forschner T. Current state of vitiligo therapyevidence-based analysis of the literature. J Deutsch Dermatol Ges. 2007;5(6):467-75.

12. Osman A, Elkordufani Y, Abdullah M. The psychological impact of vitiligo in adult Sudanese patients. Afr J Psychiatry. 2009;12(4):284-6.

13. Robaee AAA, Zolibani AA, Al-Shobaili $\mathrm{H}$. Knowledge and attitude towards vitiligo in Qassim Locality, Saudi Arabia. J Pakistan Assoc Dermatol. 2008;18:78-83.

14. Farhan Z, Ibrahim K, Sriati A. Faktor stres keluarga akibat anggota keluarganya dirawat di General Intensive Care Unit. MKB. 2014;46(3):150-4.

15. Taieb A, Picardo M. The definition and assessment of vitiligo: a consensus report of the Vitiligo European Task Force. Pigment Cell Res. 2007;20(1):27-35.

16. Hu Z, Liu J, Ma S, Yang S, Zhang X. Profile of childhood vitiligo in China: an analysis of 541 patients. Pediatr Dermatol Clin. 2006;23(2):114-6.

17. Dogra S, Parsad D, Handa S, Kanwar A. Late onset vitiligo: a study of 182 patients. Int J Dermatol. 2005;44(3):93-196.

18. Akrem J, Baroudi A, Aichi T, Houch F, Hamdaoui M. Profile of vitiligo in the South of Tunisia. Int J Dermatol. 2008;47(7):670-4. 